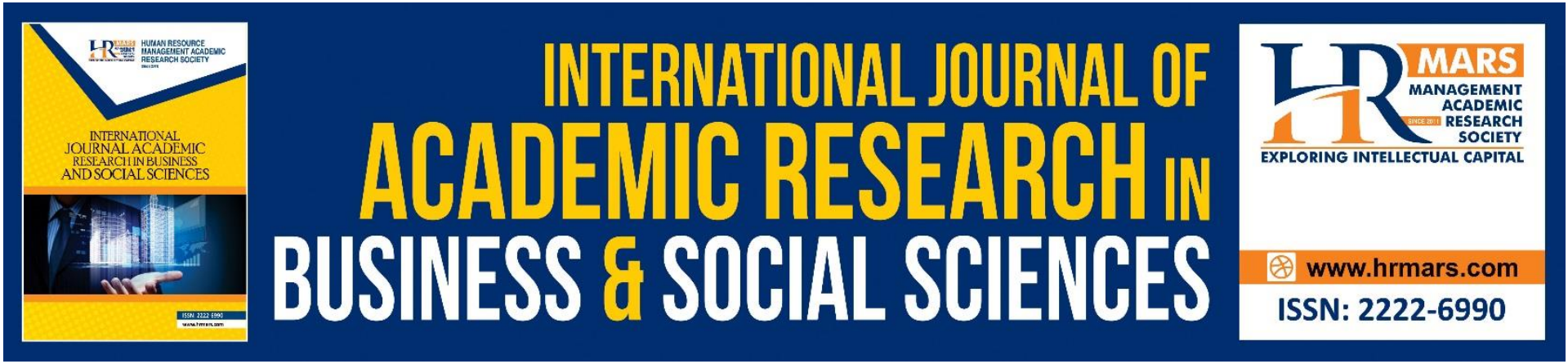

\title{
Ethics and Civilization in Malaysian Multiracial Society
}

Amini Amir Abdullah, Mohd Daud Awang, Mohammad Nidzam Abdul Kadir, Ahmad Faathin Mohd. Fadzil \& Dayang Hazieqa Hamzani

To Link this Article: http://dx.doi.org/10.6007/IJARBSS/v11-i12/11940～DOI:10.6007/IJARBSS/v11-i12/11940

Received: 22 October 2021, Revised: 26 November 2021, Accepted: 10 December 2021

Published Online: 24 December 2021

In-Text Citation: (Abdullah et al., 2021)

To Cite this Article: Abdullah, A. A., Awang, M. D., Kadir, M. N. A., Fadzil, A. F. M., \& Hamzani, D. H. (2021). Ethics and Civilization in Malaysian Multiracial Society. International Journal of Academic Research in Business and Social Sciences, 11(12), 2115-2141.

Copyright: @ 2021 The Author(s)

Published by Human Resource Management Academic Research Society (www.hrmars.com) This article is published under the Creative Commons Attribution (CC BY 4.0) license. Anyone may reproduce, distribute, translate and create derivative works of this article (for both commercial and non0-commercial purposes), subject to full attribution to the original publication and authors. The full terms of this license may be seen at: http://creativecommons.org/licences/by/4.0/legalcode

Vol. 11, No. 12, 2021, Pg. 2115- 2141

Full Terms \& Conditions of access and use can be found at http://hrmars.com/index.php/pages/detail/publication-ethics 


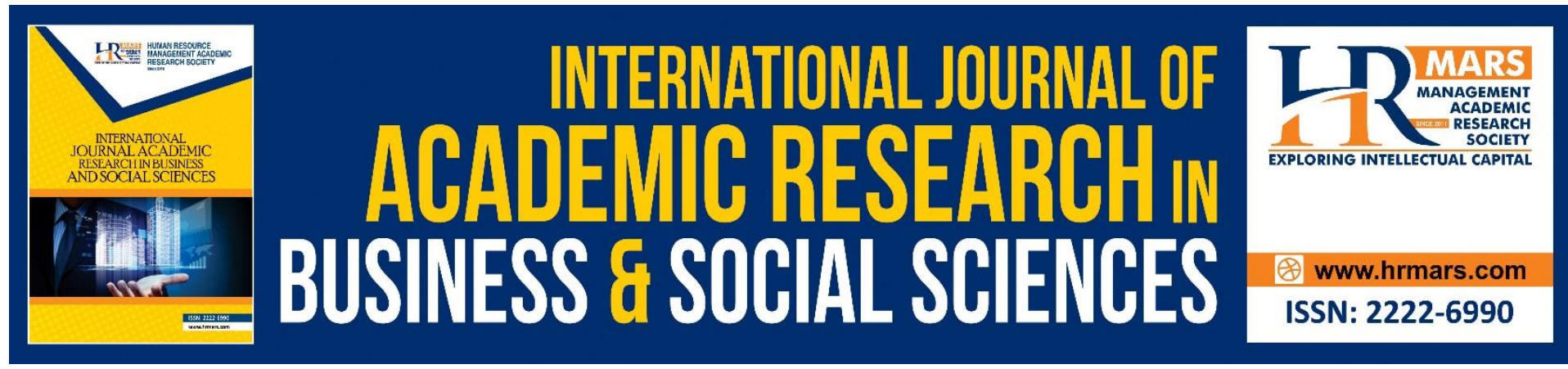

\title{
Ethics and Civilization in Malaysian Multiracial Society
}

\author{
Amini Amir Abdullah', Mohd Daud Awang ${ }^{1,2}$, Mohammad \\ Nidzam Abdul Kadir ${ }^{1}$, Ahmad Faathin Mohd. Fadzil ${ }^{1}$ \& Dayang \\ Hazieqa Hamzani ${ }^{1}$ \\ ${ }^{1}$ Faculty of Human Ecology, Universiti Putra Malaysia, ${ }^{2}$ Halal Products Research Institute, \\ UPM. \\ Email: amini@upm.edu.my
}

\begin{abstract}
This paper discussed the spirit of ethic and civilization in the Malay world through the compulsory course of public universities in Malaysia, namely Internalization of Ethics and Civilization which was first introduced in 2020. This paper focused on multiracial society in economics context and historical context and aims to understand the Malaysian experiences of the concept of ethics and civilization based on Malaysian Mold (acuan-Malaysia). Malaysia has long struggled to manage ethnic diversity towards the formation of an integrated and united in a broad sense that encompasses socio-cultural, socio-economic and socio-politic aspects since 1957 as a national agenda. The fact is that the phenomenon of ethnic diversity is a legacy of British colonialism where Malaysia does not have much choice, but to accept and manage it as best as possible. Unfortunately, efforts to form a national identity often collide with a strong ethnic identity in the society. Thus, we need to improve the understanding of the concept of ethics and civilization among Malaysians to be united and live-in harmony, developed and prosperous. The fundamental value that must be present in every ethnic group is mutual respect, mutual understanding and mutual trust in each other attitudes.
\end{abstract}

Keywords: Ethics, Civilization, Malaysia, Ethnic Diversity, Malay World

\section{Introduction}

Malaysia is one of the countries with a multi-ethnic population. Ethnic diversity shows a strong influence in the political practices and daily life of the people of this country. Ethnic awareness becomes a major part of self-identity in the lives of the society. Thus, the question of ethnic diversity in modern society is usually associated with the rise of nationalism, nationbuilding and ethnic conflict. In general, the characteristics of a multi-ethnic society in Malaysia are often understood as a feature in the country's population that only emerged or produced during the British colonial era. In addition, the ethnic diversity of Malaysian society is also often dominated by popular understanding that is more focused on the multi-ethnic society that exists in the region of Peninsular Malaysia. In this regard, ethnic diversity among local or 
indigenous communities is undeniably a feature that has existed long before the British colonial process took root in Malaysia.

In fact, in Malay world the interaction Malay with other ethnics have been existence traditionally. It is already existed the cycle of migration and integration in Malay Archipelago with Indian civilization, Chinese civilization, the Middle East and the Malay world each with a unique system of ethics, through the Straits of Malacca between South China Sea and the Indian Ocean. This interaction became an important fundamental of ethics and civilization in Malay world.

After the arrival of Europeans in Malay world, they started to introduce the European civilization and ethical systems in Malay society. In this time also the cultural and ethnic diversity became more concentrated and complex due to Chinese and Indian people brought into labor with huge number in Malay land by Europeans. Therefore, the phenomena of migration and diversity are inseparable in discussing ethics and civilization in a multiracial society. The overlapping of each element of the various ethics and civilization, the East and the West, finally stitched through assimilation, accommodation, acculturation and amalgamation, which took place from the level of the masses up to the pinnacle of the Malacca Sultanate. Through the migration of forced labor, there was a plural society during the colonial period and continues to this day.

In this subject, the discussion on Multi Racial Society is the main point in issues of ethnic and civilization in Malaysia. In fact, the situation and characteristics of other ethnic vary more than that including ethnics in Sabah and Sarawak. This indicated that Malay people have a long history in ethnic diversity of early society or at the level of local communities although ethnic diversity in certain regions are poorly understood or given priority. Therefore, this subject was introduced to strengthen the development of ethics and civilization which are the main features of development and progress. Among the ideas that will be discussed in this paper include the philosophy and terminology "Bangsa Malaysia" which has long been embedded in the Federal Constitution. It was later officially introduced by Tun Abdul Razak on June 20, 1970 and further proclaimed by Dr. Mahathir while launching WAWASAN 2020 (Vision, 2020).

\section{The Reality of Ethics}

Imam al-Ghazali r.a is a scholar who highlights various ethical and moral ideas derived from the Qur'an and Sunnah. For Al-Ghazali (2003), the classification of knowledge is best done in the context of the division of religious knowledge and intellectual knowledge (rational and intellectual). Evidently, by choosing to discuss the ethical-law status of knowledge in relation to the division of religious knowledge and intellect, Al-Ghazali intends to prove that not only methodologically but also ethically, religious knowledge is a class of knowledge superior to intellect. His debates and discussions on ethics and morals transcend his time and cover almost every aspect of human life. He also highlighted the significance of tasawwuf and the principles of sound and practical Islamic ethics and morality. This is one of al-Ghazali's authoritative and contributions in the history of Islamic thought to this day. His wisdom was so highly praised that he was called "Hujjatul Islam". This title is a recognition of the Muslim community for his greatness, knowledge and personality and he is an 'Hujjah' (argument) about the truth and dynamics of Islam itself (Amini, 1990). Imam Al-Ghazali is known as an 
Islamic figure who has his own perceptions or opinions on ethics and morality. This notion forms a unique thinking on the concept of ethics and morals in Islam.

Ethics and morality cannot be separated, and it is futile to think of its separation. This is because morality is a condition that is embedded in the soul and manifests behavior. AlGhazali has also succeeded in proving that the idea of thought and the concept of morality that he brought is the concept of morality that leads to Islamic knowledge and discipline, not morality that is deviated from the sacred values of Islam and not contrary to Islam. We should focus the discussion on the perceptions, opinions and ideas put forward by Imam al-Ghazali on the conception and perception of Islamic morality that leads to improving all aspects related to the spiritual and physical human to gain the pleasure of God and in line with the preparation for retribution in afterlife. The integrity of the concept of morality as explained by al-Ghazali in such a wide scope is a superior idea that was once produced by an Islamic scholar. It covers almost all human life whose purpose is to lead human beings towards the straight path and save mankind in this world and the hereafter (Amini, 1990).

In this subject, the researchers will focus on the significance of the approach used by the main Muslim scholar in Malaysia, Imam Al-Ghazali. The concept of Islamic morality according to Imam al-Ghazali is very clear on the problem of human attitude, behavior and deeds and these should also be discussed.

Furthermore, the debate should be focused on the initiative to highlight the true and accurate teachings of Islam related to human ethics and morals in the context of Imam Al-Ghazali's thought without ignoring the original goals of Islamic teachings in order to fulfill the ideals and goals determined by Allah. Readers can examine and take heed of how al-Ghazali expresses moral questions in such an interesting and effective style and apply Al-Ghazali's approach to responding to solving current problems and addressing the moral crisis that has so deepened in recent times. As such, we should take the consideration of the knowledge of some of al-Ghazali's ideas, concepts and epistemology in highlighting the significance of Islamic ethics morality.

The essence of ethics is to seek wisdom by asking about what is right and wrong, what is good and bad. Muslim scholars have elaborated the concepts of Islamic morality from the Qur'an, the Sunnah and their social and spiritual experiences. What is said to be good by the revelation of Allah, then it is necessarily good for all human beings and vice versa. The good or bad balance of a thing or deed is not determined by man but is determined by Allah SWT. because the human mind does not reach the highest level of evaluating a good or bad thing except Allah SWT.

Ethics comes from the Greek ethos which means character. The concept of morality comes from Latin terminology, moralism which means custom or manners. Usually, we talk about ethical or moral people which means good or right while unethical and immoral means wrong or bad. So, the central point that determines something is good or bad is human beings or society (Masumi, 1992). This is different from Islamic morality where the morality is determined by Allah SWT. and will be questioned in the Hereafter. Good morals will be rewarded with heaven and rewarded with goodness in the Hereafter while bad morals will be rewarded with hell and will be punished in the Hereafter.

The philosophy of ethics is the study of what makes something moral or ethical, good or right, and unethical or evil or wrong. Philosophers have considered what makes something morally good or bad, right or wrong in relation to various features in the reality of human life (Byrne, 
1992). For example, does moral virtue involve some relationship with happiness or pleasure? In Islam, good, bad, wrong, happiness and pleasure are determined by Allah SWT. All obligatory things are good, rewarded virtues such as prayer, hajj, fasting in the month of Ramadan and performing hajj. The same is true for encouraged deeds (sunnah). All illegal things are faults and vices. While all permissible acts should be good and usually approved by human beings. All things that are makruh (hated) are bad because they are hated by Allah SWT.

Does something good involve excellence, harmony and creativity? Is it possible to be indifferent in terms of right and wrong? What is unethical? For example, my pen that I use to write, can be immoral. If a pen is used to sow slander, lie, sheepish, slander, gossip and the like, then it is immoral. But if the pen is used to express the truth, write letters to parents and the like, then it is a moral act. But if the pen is used as a weapon to spread fake news, it enters the domain of immorality. In summary, ethics is the moral principles or moral values (customs, morals, manners, and the like) that are held by an individual or a group of people. In the context of a multi-racial society in Malaysia, it is the practice and appreciation of their respective religions that manifest good and commendable behaviors and attitudes. Therefore, this subject has emphasized values of religion in appreciation on the moral principles.

\section{The Reality of Civilization}

Civilization is the state and level of progress in physical and spiritual life (Kamus Dewan Edisi Ketiga, 1994: 6). While the term civilization refers to the state of society characterized by or based on the level of material progress as well as the development of thought whether social, cultural, political and others (Kamus Dewan Edisi Ketiga, 1994: 1355).

The Arab terminology "tamaddun" was Malaynized to the term "tamadun". The term is usually used synonymously with the noun, civilization. The term civilization is usually used in conjunction with the meaning of hadarah which also means civilization. The Arabic term "tamaddun" refers to the elements of urbanization and township, settlement, urban life, urban development, inland or upstream, cosmopolitan, urban, urban construction and civilization as well as the way of life, culture and behavior and attitudes of the people living in a cosmopolitan, city or town (Bek, 1980).

The Merriam Webster Dictionary (2016) defines civilization as a relatively high level of technological and cultural development and specifically a stage of cultural development in which the writing and keeping of written records has already taken place.

Another term that describes the characteristics of human civilization is 'umran. The term was introduced by Ibn Khaldun. 'Umran refers to human settlement, land of occupation, period of settlement, group of settled human beings, natural fertility and well-being and harmonious life. Bek (1980) sees civilization more as the result of civilization, namely in achievement, progress and material and human development. These achievements are more evident in the fields of politics, law, construction, culture, urbanization and writing. To be civilized means to be well-mannered, well-behaved, civilized, cultured, praiseworthy, and progressive.

Being civilized does not merely mean civilized, but also means moving forward in all fields including physical and spiritual progress (spiritual and physical) as well as mental, emotional, improving living standards to a better position, cultivating quality and ways of working for development. and progress of life, high culture, good manners, noble morals, high Intelligence Quotient (IQ), Emotional Quotient (EQ) and Spiritual Quotient (SQ), polite, ethical, virtuous, courteous and civilized as well as noble rituals. Civilization symbolizes the 
identity and image of a nation with a high perspective. A nation is not called civilized or civilized race if it does not have a culture of reading, a culture of seeking knowledge, a culture of researching, a culture of observing, a culture of studying, a culture of experimentation, a culture of empirical study and a culture of thinking.

Islam was born in Hijaz, the Arabian Peninsula which consists of various tribes, clans and tribes. Before the advent of Islam, the society of the Arabian Peninsula was known as the Jahiliyyah Arab society. They are not ignorant in the aspects of civilization and progress, but they are ignorant in the aspects of spirituality, virtue, and morality. According to Amini (2014), the Jahiliyyah Arab society is divided into two groups:

1. Bedouin Arabs-They practice a nomadic life, living in the interior, the middle of the desert and are commonly called the uncivilized Arabs.

2. Hadari Arab community-Their life is characterized by a way of life settled (not nomadic), living in cities/towns such as Makkah, Madinah and Taif.

\section{The Meaning of Civilization and the Impact of Science and Technology}

Civilization means human achievement and development in all fields, including physical and spiritual forms. In the science of civilization, what is said to be development is the human achievements in all aspects of life to improve and develop that benefit the society. It includes developments in industry, handicrafts, science and technology, agriculture, economy, improvement of living standards, literature, culture, arts and belief systems.

In short, human beings want to increase productivity and standard of living as well as quality of life for the sake of survival and continuity of life. In early human and medieval times, we would find that discussions of the implications of science and technology from a negative angle did not get serious coverage. Even the early human civilizations such as the civilizations of Mesopotamia, the Euphrates, Greece, Egypt, Sumeria, the Indus River Valley and the Chinese Civilization did not suffer a decline due to the negative impact of science and technology. It is more closely related in matters of humanity, integrity, misuse of power and negative human attitudes as well as other negative factors. It is nothing to do on science and technology per se. In short, civilization is the system and level of social development of a nation; the social and cultural progress of a nation is based on religious appreciation and not purely material progress.

Imam Al-Ghazali r.a has proved through his initiative that creating and academic writing can have a great impact on the development and progress of human civilization. What's more, his great work brings about a huge change to the way we think and behave (Amini, 1990).

\section{The Understanding of Malaysian Multi Racial Society}

The ethical and civilizational components in the physical geographical environment are particularly important to examine. Malaysia's geophysical environment is very strategic. Usually an ethnic group has historical, traditional and cultural ties with the environment of a particular geographical area (Shamsul, 2008a).

Historians seem unprepared to accept that Islam spread in the Malay Archipelago before the thirteenth century although many reasons were given to them to convince them that Islam was already a vital force and influential before that time. However, D.G.E. Hall (1981) claims that the tombstone in Leran dated 1082 was brought there at a later period. Hall (1981: 221) 
added: "...even if the date is genuine, the inscription does no more than indicate the presence of an Arab, or Persian, there in about 1100. There is no evidence of the spread of Islam to that area until long afterwards". This conclusion contradicted to the resolution of the Indonesian historians in a seminar on the 'History of the Coming of Islam to Indonesia' that Islam came to Indonesia in the first century of Hijriyyah (i.e. $7^{\text {th }}$ or $8^{\text {th }}$ century A.D.) directly from the Arab region. Their evidence is that there were records of Muslim inhabitants along the coastal area of Sumatera (Ishak, 1995). In fact, Arnold (1968) is of the opinion that Islam was brought to Malay Archipelago as early as seventh century A.D.

Islam slowly took root in the region. A Chinese source stated that in the year 977 A.D., a Muslim representative from Poni (Brunei) called Abu 'Ali has visited China (Hirth and Rockhill, 1966). This indicates that Islam had already started to spread in the Malay Archipelago. The representative perhaps was appointed by a state in the Malay Archipelago with a special task to visit China. The first region occupied by Islam was the coastal area of Sumatera in 1204 A.D. and at that time the Muslim community was established (Fatimi, 1963). Marco Polo in his account mentions that Perlak on the North-East coast of Sumatera had a Muslim community in 1292. After this century, the spread of Islam was very rapid. Samudra and Pasai were converted a few years later. Pasai established a strong Muslim political power and acted as the benefactor of Islam in North Sumatra. In fact, Pasai became the earliest center of Islamic education in the Malay world (Ismail, 1986). Pasai is very important to Malaya because it is from here that Islam was introduced to Malacca.

Islam came to Malaya in the year 1303. S.Q. Fatimi proves that Islam came to the Malay Peninsula before the month of February 1303 A.D (Fatimi, 1963). The finding of Fatimi's inscriptions of Islamic law recorded on the monument in Kuala Berang, Terengganu also proved that Islam had already spread into the region in the fourteenth century. The inscription was found at a place twenty miles from the mouth of Terengganu River.

According to Hall (1981), the exact date on the inscription cannot be specified. He predicted the date probably between 1303 and 1387. Brian Harrison (1954) suggested the date either 1326 or 1386 . Although 1303 is the earliest year we have on the coming of Islam to Malaya, the spread of the religion took place not from Terengganu but from Malacca.

The propagation of Islam in the Malay Peninsula increased rapidly in the fifteenth century especially through Malacca; the main center, as well as the terminus for the great Indian Ocean maritime trading network. According to Shellabear (1961), the preaching of Islam in Malacca was propagated by an Arab merchant, Sayyid Abdul Aziz to the ruler of Malacca; Raja Kecil Besar and the community as well. Raja Kecil Besar then was given a new Muslim name as, Sultan Iskandar Shah. Islam slowly spread all over the region without any force or coercion. It is a reality that the expansion of Islam in the Malay Peninsula came through the Malay Sultans who first converted to Islam themselves and then were followed by their fellow citizens.

The geophysical of Malay Land is essentially a peninsula surrounded by the South China Sea and the Straits of Malacca as a route including the Indian Ocean and social meeting place of two great civilizations of the world, namely China and India, through trade activities. Malacca Sultanate was a symbol of multi-ethnic society assembly and cultural interactions the greatness of the Malacca empire became a meeting place for traders from all over the world, so much so that it was called 'The Venice of the East'. The age is the golden age of the Malacca Sultanate and the height of the Malay royal majesty. The greatness of Melaka can be seen from the aspects of government, trade, population and culture. Trade in Malacca runs smoothly as a result of an open system of government and efficient port administration. The 
Malacca Code (Undang-undang Kanun Melaka) is implemented to protect the safety of the sea in Malacca from the threat of robbers and pirates. This action can guarantee a high level of security to thousands of merchant ships that come to trade in Malacca. Trade in Malacca ran very smoothly as a result of the open system of government as well as the efficient administration of the port. Marine safety from the threat of robbers and pirates was controlled by the proactive Admiral of Malacca. This situation makes it a safe and peaceful environment for traders to trade in the port of Malacca, not to mention this situation is strongly supported by the Law of the Sea of Malacca which is based on Islamic teachings. Resources and agricultural products of the Malay hits trade with other civilizations, especially China, the Middle East and India.

Many factors combined to bring about Malacca's importance as a port. The first of these was Malacca's geographical position at one of the narrowest points on the Straits between Sumatra and Malay Peninsula. Thus, it was in a position to control the trade that passed by. Second, compared with the coastal ports of North-East Sumatra, Malacca had a more central position for trade with the Eastern parts of Southeast Asia. Third, it also had a better harbor than the Sumatran ports and the Chinese protection of Malacca helped to make its harbor safe.

Historically, Malaysian civilization is the embroidery of the world's plural civilizations through cultural diffusion. Trade in Malacca ran smoothly as a result of an open system of government and efficient port administration. The population pattern in Malacca is unique. Malacca Sultanate era is the era of plurality because the migration process occurs naturally without any force as compared to the colonialist era. Traders do not need a passport or visa as identification to enter an area. This situation allowed traders from Arabia, India, China and other countries to trade freely and interact with the locals. Arab traders, China, India and Indonesia also experienced through a process of assimilation and amalgamation with the locals and eventually led to the creation of a new society, a society of Baba Nyonya, Serani, Malay-Arab and Malay descent Indians. The cultural diversity in Malacca proves the gradual process of amalgamation of plural civilizations. The openness of the government of the Malacca empire to accept the presence of traders from all over the world without strict conditions caused the port of Melaka to develop as a developed and most important port in the world. The development of trade and the empire of Malacca as a metropolitan city made Malacca a multicultural city. Every culture in Malacca has its own place. Cultural pluralism is not a new phenomenon in the Malay world. The interaction of various cultures such as the pre-Islamic Arabs, Hinduism, Buddhism, Islam and Europeans such as Arabic, Portuguese, Spanish, Dutch and British in the Malay culture has occurred since the 5th century AD. The meeting of the world and the clash of cultures has produced a special feature of social phenomena in the Malay world, namely cultural plurality phenomenon. Malacca Sultanate era was the golden age and the height of the Malay royal majesty. Malacca also was ruled by far-sighted sultans and dignitaries.

Thus, with the heritage of different value systems and civilizations, each ethnic community at that time was able to live together in peace and harmony. Each party can be seen interacting and the relationship between members of society consisting of various ethnicities and religions at that time was complementary in nature and interdependent in a long chain of social cohesion. The big mold in the context of a multi-ethnic society is not static, but always dynamic in a process of continuous consolidation supported by social, economic, political and 
cultural structures. Social cohesion is built by social actors consisting of various ethnicities who are in it through daily practice. They are characterized by interactions and social relationships that are intertwined, interconnected and even shared. Therefore, the interaction and interweaving of such social relationships is something that is directly or indirectly embroidered into the social fabric of society because they are all in one big mold of the same nation-state accordingly.

Society means a group of people who form a system of social interaction in which most of the interactions that take place within the social system are born from the individuals who are in the group. The characteristics of society are grouped, cultured, undergoing change, interacting, having leadership and having its social order (stratification, class, status and caste). In other words, a society is a group of human beings who live and work together until they can orient themselves and think of themselves as a social unit that has certain boundaries. With such a complex ethnic, religious, cultural and linguistic composition, Malaysia has managed to maintain harmony in community life as well as development achievements. Thus, the uniqueness of national governance in cultivating unity in diversity is very important than just looking at the dimensions of conflict or tension. This aspect of unity governance in diversity actually leads to an understanding of the process of social cohesion in society which is in fact the essence of stability, peace and harmony in multiethnic society (Shamsul, 2014).

Furnivall (1948) proposed the concept of a plural society to identify the society in Southeast Asia, the area where there is a chain of people, namely Europeans, Malays, Chinese, Indians, and various groups of local children. Furnivall explained that they associate but do not join with each group adhering to its own religion, culture, language, ideas and way of life. According to Furnivall (1948), as individuals they meet, but only in the market, while buying and selling. There is a plural society with various parts of the community living side by side, but separately, in the same political unit. In the field of economics, the division of labor takes place along racial lines. In other words, a plural society is mixed with each other but not united. They live close together but are not separated by the same political system and each adheres to their own culture, religion, language and thought. In terms of the theoretical framework, the theory of plural society by Furnivall is still used as reference material to discuss ethnic relations in Malaysia. In addition to having the parameters of each ethnic group, ethnic Malays, Kadazan, Bajau, Bidayuh, Iban, Chinese, Indians, and others are found to have received the local culture and not living apart as illustrated in a plural society modelled by Furnivall.

The multiethnic Malaysian society has different cultural, religious, linguistic and customs backgrounds. Although these different ethnicities work together under the same political system, their lives are separate. Interaction among them is also less and the relationship between them is limited to certain things especially those related to economic activities. The division of labor in the economic system is made on the basis of ethnic segregation in society with each ethnicity having its own economic function (Shamsul, 2010). However, the atmosphere is much better when compared to the atmosphere during the newly independent Malay Land. The society at that time conformed to the characteristics of a plural society as expressed by Furnivall (1948), the effect of the implementation of the policy of divide and rule and order by the British. 
Plural society consists of various nations that make up a population of living as communities apart and in Malaya, there are three main ethnic Malays, Chinese and Indians in the peninsula, Sabah Bumiputera like Kadazan-Dusun, Bajau and other and Sarawak Bumiputera like Iban, Melanau and others who are not only separated because of customs, food and clothing but also in terms of employment and shelter. The existence of a plural society is in line with the colonists who came to Malay Land in the past by bringing in all these people to meet employment opportunities in Malay Land.

\section{From Plurality to Diversity}

The term plural society used to refer to people of various ethnic groups in the presence of colonial Malaya after bringing in immigrants from China and India's economic interests. The slogans of 'unity in diversity' and 'national unity' are a positive hope for a brighter future than now, including our ambition to realize the 'dream nation', namely 'Bangsa Malaysia.' Instead, what we actually support and braces, even a phenomenon that we have never given any name to all this time but continue to enjoy is the concept of social cohesion (Shamsul, 2010).

The pattern of population composition and diversity that exists indirectly encourages the perspective that ethnic relations in Malaysia in general are fragile and prone to tensions and often lead to conflict situations. Is such a view accurate to describe ethnic relations in Malaysia? If such a view is accepted, Malaysia as a nation may not be able to survive and exist on the world map. The prevailing situation is that these diverse ethnicities will form a country according to their respective ethnic molds. Nevertheless, the fact is that Malaysia with its different demographic composition continues to be strong, developed and developing and even respected by its neighbors in the context of a complex multiethnic country.

Other ethnicities also have a variety of religious complexities, and even overlap with other categories. Ethnic Chinese, Indian, Iban, Kadazan as well as Christianity, Hinduism, Buddhism and others also have their own diversity and composition of such ethnic Malays and Islam. The complexity is not only as explained but this social category is also liquid and moves freely and can change and differ from each other without the existence of strict and permanent boundaries (Shamsul, 2008b). The most notable example is the issue of the use of the word Allah by non-Muslims which once arose and became a pretty hot issue some time ago. If we look closely at the discourse that existed at that time in response to the issue, there are various views both supporting and opposing either from Muslims or non-Muslims themselves. Each has different views even though they are from the same religious group. Based on this example it can be clearly seen how perspectives of conflict paradigm tend to be interpreted easily.

In describing ethnic relations, there are scholars who state that a society that has a complex culture, language, religion and ethnic pluralism as in Malaysia will certainly be separated and isolated according to ethnic groups, religions, cultures and languages without values that can bind them together. In addition, ethnic differences will give rise to competition between ethnic groups to the point of extinction of ethnic characteristics, namely in terms of their language, culture and religion when the dominant ethnicity dominates the minority ethnicity. As a result, is it fair to portray ethnic relations in Malaysia in a narrow perspective by looking at Malaysian society only from the point of view of conflicts, disputes, contradictions and tensions (Shamsul, 2009). Where is the assessment of society as a whole to see the success of the country in managing the question of social cohesion enjoyed by all walks of life after the events of May 13, 1969 until today and the success of the Malaysian economy which is competitive on par with other countries? Therefore, ethnic relations in Malaysia need to be 
seen from the perspective and dimension of social cohesion which is the formula for the wellbeing of a multi-ethnic society.

\section{Ethnic Diversity and the Appreciation of Ethics and Civilisation in the Malaysian Economic Context}

During the Malacca Malay sultanate, the ability of the Malay community in the market world cannot be underestimated. There are a group of international-class entrepreneurs and traders doing business in the pan-Asian trade network (Farish, 2019). For this reason, the aim of the Spaniards and Portuguese was to invade and conquer several kingdoms in Southeast Asia, with the intention of expanding their own trade networks from Europe to Asia as well as to weaken the pan-Asian trade networks that the Asians themselves had developed. The fertile land of Malaya and its rich produce caused many to do business with the Malay world. In addition, the existence of its strategic ports makes it a developed intraport. Port Melaka was a very developed port at that time. According to Abdul Kadir (1996), Melaka developed from a small village to a state and then a busy port after its king converted to Islam. The narrative history of the Asian world was so dynamic yet complex, before the arrival of the Europeans. Southeast Asians live their economic lives by working, trading and interacting with each other in a global economic system. He added that Southeast Asia had been home to several important trade centers such as Melaka and Banten which were interdependent with each other. The global Asian network covers the region from China to Southeast Asia (Malaya) to India. Open economic development is the key to the harmony of the Malay community and its neighbors. This economic system is ready to open space for all kinds of international trade activities. In addition to the ability of its people to forge close economic ties with its neighbors as well as other governments outside the Southeast Asian region. This approach is not only pragmatic but also the key to the political-economic success of the Malay government.

\section{i) Biography of the Malay World Ethnics in Economics: The Pre-Colonial, Colonial and Post-Colonial Era}

The claim that in pre-colonial times the Malays only practiced in subsistence economic activities is doubtful. Most historical articles of Melaka show that during the Sultanate of Melaka, trade activities have been established and are the most important activity besides other economic activities such as agriculture and carpentry and others. The meaning of traditional economic practices at that time were a general picture to the Malay community but did not deny the ability and involvement of the Malays in global trade. In fact, the Malay, Chinese and Indian communities before the arrival of Europeans had already formed strategic trade relations known as pan-Asian trade networks (Farish, 2019).

During the colonial era in Malay world, the British continued to dominate economic activities in the states of Malaya with the opening of tin mines and rubber plantations as well as the influx of labor in large numbers from China and India. The British encouraged the massive entry of Chinese and Indian laborers to work in tin mines, plantations and factories. That policy contributed to the existence of a plural society in Malaya. Furnivall (1948: 304) defined a plural society as "...a society that is, comprising two or more elements or social orders which live side by side, yet without mingling, in one political unit." He further says that in the plural society "... different sections of the community (live) side by side but separately, within the same political unit" (Ibid: 305) He further adds "Each group holds its own religion, its own 
culture and language, its own ideas and ways... Even in the economic sphere there is division of labour along racial lines" (Ibid).

In 1931, the number of Chinese and Indians in Malaya exceeded the number of the Malay population. The existence of a plural society has resulted in a political and social problem and become an obstacle in the process of unity, integrity, and the achievement of independence. Every single race lives separately and maintains its own culture and identity. The interaction between the races is very limited and they are also separated by economic divisions. The majority of Malays live in rural areas and work as farmers, fishermen, or rubber tappers while the majority of the Chinese live in urban areas and are involved in business and mining sectors. On the other hand, the majority of the Indians work in plantations.

Instead of forming a multiracial society in Malaya, the failure of the Chinese and Indian immigrants to integrate into Malayan society meant that Malaya became a country with a plural society. Different ethnic groups preserved their own beliefs, customs and lifestyles. Every ethnic group had different patterns of residence. The Malays lived mostly in the rural areas; the Chinese tended to live mostly in towns, and the Indians were concentrated mostly on the estates and plantations. Different occupations of the three nationalities was one of the reasons for the different patterns of residence. Whilst the Chinese were mostly miners or businessmen, the Malays continued to concentrate on farming and fishing, and the Indians on working in rubber plantations.

The three nationalities carried with them different religions. They practiced their own traditions, customs, value systems, and norms. The varied beliefs and practices served to point out the distinct differences between the cultures. Since the educational system introduced by the British was almost entirely in English with a minority of Malays studying in their schools, the majority being Chinese and Indians, education sharpened the divisions between the nationalities. Schooling at this time also depended on individual communities setting up their own schools and teaching in the vernacular. This also contributed to the divisions between the races.

Every ethnic group set up its own political and social associations. Already divided in lifestyle, language, custom and religion, these associations segregated the lives of the people even more. The Chinese brought with them their secret societies (kongsi gelap). The secret societies caused one of the more serious problems in the Straits Settlements in the nineteenth and twentieth centuries. The societies were mainly built on clan foundations. At first, they concentrated largely on assisting the economic and social needs of the newly arrived immigrants. The Chinese immigrants found themselves living in poverty in a country whose customs were unfamiliar to them, ruled by people whose language they could not speak, and which seemed indifferent to their well-being. They must have suffered a terrible feeling of insecurity and isolation. It was membership of the secret societies that helped solve their problems (Ratnam, 1967: 7). Further, the secret societies became involved in organizing gambling and prostitution activities, and opium smuggling amongst the Chinese community and there was often open warfare between the different societies. By the nineteenth century, due largely to the Chinese secret society activities and other factors, the country was thrown into political chaos (Hua, 1983: 58).

In early the $20^{\text {th }}$ century, the Indians began to set up associations in most towns and districts to protect their interests. These finally came together in 1937 to form the Central Indian Association. According to Hua (1983), the setting up of the Unemployment Relief Committees marked the beginning of a greater mutual assistance in the Indian community. The Malays 
also set up their own organizations to unify their people. On $14^{\text {th }}$ May 1926, the Malay Association of Singapore (Kesatuan Melayu Singapura) was formed under the leadership of Muhammad Eunos. This organisation was established with the purpose of defending the rights of the Malays who have found themselves a minority and the most deprived lot in an urban economy controlled by immigrant races and directly ruled by a colonial administration. Under the impact of social and economic upheaval caused by depression and the challenges from immigrant populations, there was some interest shown by the Malays to set up expressly political associations to defend and represent Malay interests, as distinct from the existing welfare associations which were mostly of a local kind (Lim, 1972: 55). Between 1937 and 1939 Malay political organisations were established in Province Wellesley (Seberang Perai), Selangor, Negeri Sembilan, and Pahang (Roff, 1968). The polarisation of Malayan society into three separate nationalities was one of the major consequences of nineteenth century immigration. It was only in the second half of the twentieth century that concrete efforts were made by the Malayan government to integrate the different communities.

In the post-colonial era, the government has undertaken a strategy of social restructuring to resolve the unbalanced position in terms of economic dominance among the races and promote the economic progress of all sections of society so that gaps between societies can be eliminated.

The Malays felt that Malaya was a Malay country. In the first stage, they became aware of the adverse economic position of their community. They started to realize that their participation in the process of development, economic growth, urbanization and modernization was characterized by a growing political and economic dependence. In the second stage, pre-war Malay nationalism was partly a response to the arrogant and the growing demands of the non-Malay communities such as the demand for equal special rights and privileges. During this time also, the Malay nationalist efforts were to combat non-Malay threats and their activities were concentrated on the resentment towards non-Malay ambitions. In the third stage, they started to doubt whether the Malay culture, custom and language could survive in an increasingly heterogeneous milieu and they were afraid of the danger of "...converting their race into an "aboriginal stock" and their culture into a museum piece" (Silcock and Aziz, 1953: 286).

In the final stage, the post-independence Malaya witnessed a growing tendency for Malays to assert their superior claims in the country. A Malay newspaper reminding the non-Malays that they are "...only staying in other people's homes and there will be a time when they will have to quit when the owners claim it back" (Ratnam, 1967: 24). How the spirit of Malay nationalism probably perverted the national unity can be observed from this statement:

The Malays had two important preoccupations, both arising from their desire to safeguard their political preeminence in the country: first, they wanted the constitution to serve as an instrument that would give Malaya certain external features of a Malay state: second, they wanted to secure political and economic advantages that would help them improve their position in relation to the other communities (Ratnam, 1969: 352)

The factors that separate different ethnic group also related to the process of development and achievement among various ethnic groups. The Malays are concentrated in the rural areas and they are relatively poor. As stated by Mills (1958: 5): "...they used to be poor men in a poor country, and now they were poor men in a rich country". They are involved with agriculture, especially in paddy and rubber. The majority of the Chinese are concentrated in the town areas and involved with urban occupations such as management in manufacturing, 
construction, and business. They are relatively rich. This creates dissatisfaction among the Malays. This sort of segregation and condition made the social gap between both ethnic groups wider because each ethnic group is dissatisfied with their counterpart's status quo. The contrast between the poverty of the Malays and the richness of the Chinese caused the hatred of the Malays toward the rich, of whom the large number are Chinese. But the hatred toward the rich Chinese was not because they are not Muslims.

The conquest of the Japanese saw a rise in the development of nationalism especially among the Malays. The different treatment of the different races by the Japanese made them realize that they themselves should shape their destiny instead of letting foreign powers run their life and country. Finally, in defending the rights, power and interest of their own communities, politicians and ethnic leaders always highlighted racial sentiments and issues intentionally or unintentionally. Provocative and sensitive words lead to the tragedy of May $13^{\text {th }}, 1969$.

On $31^{\text {st }}$ August 1957, the Federation of Malaya (included their Straits Settlements i.e. Penang, Melaka, and Singapore; and all states) secured its independence from Britain. On $31^{\text {st }}$ August 1963, Sabah and Sarawak joined to form Malaysia. Singapore, which was part of the Malay Peninsular for centuries, ended its membership and became an independent state in August 1965 (Smith and Bastin, 1967: 83). The first post-independent government was ruled by an alliance coalition of three major ethnic-based political parties comprised of the United Malay national Organisation (UMNO), the Malayan Chinese Association (MCA), and Malayan Indian Congress (MIC).

Two major reasons contributed to Malaya's attainment of independence, two years earlier than expected by the Alliance. First, the ability of the three major races to come together into a political alliance. Second, the existence of the Emergency. The British government had made it almost a pre-condition for independence that the three major races in Malaya must first be able to cooperate politically. The British government, realizing the strong differences existing between different races, made this political cooperation as a pre-requisite to independence. In the early stage of the Emergency, the British were of the view that all efforts must be concentrated on suppressing the communist insurgency and that constitutional and political advancement would have to wait. But later, the British realized that the communists could not be regarded as a pure military matter and therefore, constitutional and political progress gained more emphasis (Zainal, 1980).

In the new Malaysia, the Malays and many non-Malays became citizens. Malay became the official language, but other languages were to be freely spoken and taught. Islam became the official religion. The states have legislative and executive authority over it. It is a sort of agreement between the Malays and non-Malays that only Malays may hold the position of Prime Minister, Chief Minister, Governor and Paramount Ruler. The constitution also safeguarded the Malays' special privileges, including the reservation of positions in the public services, places and scholarships at educational institutions, and permits and licenses that are required to conduct certain types of trade and business, and the continuing reservation of land. These special rights were subject to criticism and gave the Chinese and Indians a set of common political interests (Ross-Larson, 1980).

The population of Malaya in 1957 was 50 per cent Malays of the 6.3 million, the Chinese 37 per cent, Indian's 11 percent and others 2 per cent. The rural-urban distribution of population shows that there are more non-Malays in the urban than in rural areas. The percentage of the urban population was 26.5 per cent, with the Chinese comprising 63 per cent (the largest), followed by the Malays ( 21 per cent), Indians 13 per cent and others 3 per cent. The Malays were mainly in the economically less developed states of Pahang, Perlis, Kedah, Kelantan, and 
Terengganu. The Chinese and Indian populations were greater in states where British influence had been greatest and where economic activities were heavily concentrated, particularly in Penang, Malacca, Singapore, Perak, and Selangor. Works documenting this aspect of Malaysian history include Selvaratnam (1974) and Cham (1977).

Economically the Malays, Chinese and Indians held widely different positions. The Malays were in the lowest economic position. The Chinese were in the strongest position, had relatively large amounts of wealth and better education, and experience. The Indians were between the two. Nevertheless, in politics, the Malays had already seized the initiative, due to their historical advantage of legitimacy and their earlier development of nationalism. Although there is still a concentration of the three ethnic groups at certain points in the Malaysian socio-economic structures, this is more the result of historical development rather then because of racial characteristics per se.

The Malays felt frustrated and deprived with their worsening economic condition. Three factors led to these feelings. First, the increasing of capital among the Chinese and Europeans, second, the limitations of the government's effort to promote Malay capitalism, and third, the increasing poverty in rural areas in the early years after independence. Some actions were taken to increase government participation in the economy with the establishment of Bank Bumiputera in 1965 and Majlis Amanah Rakyat (MARA) in 1966 to promote Malay capitalism (Ibrahim, 1993).

\section{ii) The Role of the New Economic Policy (Dasar Ekonomi Baru, DEB), Bumiputera and Non Bumiputera}

It is known that the New Economic Policy (NEP) policy's aim is to eradicate poverty of the people regardless of race. According to Ahmad (2008) the NEP has been formulated with the aim of achieving national integration and living together in harmony and peace. Two objectives were spelled out in the Second Malaysia Plan: the eradication of poverty, and the restructuring of the economy so that Bumiputras would have at least 30 per cent employment in, and ownership of, the economy by 1990. (c) The realignment of political parties through the cooptation of opposition parties into a broad coalition called the National Front, under the hegemony of UMNO (Lim, 1985: 263)." According to Lim, from the $13^{\text {th }}$ May riot, there are two major results that can be seen. First, the government had to reconsider its economic strategy and second, it multiracial political scheme this resulted in the following changes; "(a) ...constitutional amendments which, inter alia, further strengthened the status of Malay Special Rights... (b) The promulgation of the New Economic Policy (NEP) which gave added vigor and clearer guidelines to improve the economic lot of the Malays.

Following the racial violence in 1969, the government formulated the New Economic Policy (NEP) with the primary aim of promoting national unity through two objectives: the eradication of poverty irrespective of race and the restructuring of society to correct economic imbalance so as to eliminate the identification of race with economic function (The Government of Malaysia, 1971).

Under the NEP, the government concentrated on four aspects of racial economic imbalance in order to improve the economic condition of the society. Balance in terms of employment patterns, relative incomes, shares in ownership, and control of assets were the targets. The balance was to be achieved within the period of twenty years. The Plan programmed that "...within a period of 20 years, Malays and other indigenous people will manage and own at least 30 per cent of the total commercial and industrial activities in all categories and scales of operation (Faaland, Parkinson, and Saniman, 1990: 91)". 
After more than 10 years of implementation, income imbalances between races and between the urban and rural areas remained wide. In other words, the Malays were still at the bottom of the economic ladder. In the 1980s, the mean monthly income of the Indian was roughly one and half times that of the Malay, while the Chinese was roughly double that of the Malay (Faaland, Parkinson, and Saniman, 1990). Bumiputera ownership of the corporate equity increased from 1.5 per cent in 1969 to 12.5 per cent in 1980 before rising to 20.3 per cent in 1990. Gomez and Jomo (1997) argued that such figures showed the concentration of wealth among select Bumiputera individuals but did not represent the whole true Bumiputera representation of corporate ownership. They emphasized that the NEP's 30 per cent Malay wealth ownership target had enabled influential Malay politicians and businessmen with close links to UMNO leaders to accumulate wealth for themselves. However, the private individual's share of the Bumiputera stake was reported to have increased from 39 per cent in 1983 to 68 per cent in 1990. Interestingly, the private individual's share by other nonBumiputra's have increased to 47.7 per cent in 1983, as against a target for 1990 of only 40 per cent.

In spite of its failure and success, the NEP was branded a racist policy intended exclusively for the benefit of Malays at the expense of the Chinese and Indian communities. The Indian claims that their condition had deteriorated rapidly under the NEP and by the late 1980s they proposed a new positive discrimination policy to be established specifically for Indians (Gomez, 1994). Many Chinese felt deprived when Bumiputera trust agencies and public enterprises began to dominate key economic sectors. They tried to drive the attention of public enterprises to business controlled by foreigners but failed (Jesudason, 1989: 128-132). The MCA and MIC have also expressed concern about the weak official commitment in addressing the problems of poor Chinese in new villages and the predominantly Indian workers in the plantation sector. MCA also claimed that participation of the non-Malay community in the FELDA and state land agencies scheme has been insignificant. Therefore, the overall imbalance in the distributions of ownership of non-corporate asset ownership in land will further accentuate the existing disparity (Chien, 1982: 23).

When the government enacted the Petroleum Development Act (PDA) in 1974 and the Industrial Coordination Act (ICA) in 1979, the foreign and Chinese business interests condemned both. Under the Petroleum Development Act, the country's petroleum industry is under the control of PETRONAS (Petroleum National Malaysia Berhad), the national oil agency. Despite the allegation that ICA is an attempt to advance Malay interests in the country's manufacturing sector at the expense of the investors and entrepreneurs, the greatest protest was against the regulation that unexempted companies must ensure at least 30 per cent Bumiputera participation in their ventures. Even Small Chinese businesses began to feel that their economic interests and prospects for business development were threatened by the NEP and they became receptive to the call to pool their resources. Giant Chinese companies started to think of new business strategies. Thus, Chinese businessmen have increasingly co-opted influential UMNO politicians and Malay ex-civil servants as directors of their companies. By the 1990s, even medium-scale Chinese companies were beginning to incorporate influential Bumiputeras as directors (Gomez and Jomo, 1997: 4246).

\section{iii) The Challenges of NEP}

Generally, the NEP is a government effort and has succeeded in reducing the poverty rate of all races. In addition. the various government assistance to other races has never been 
forgotten. However, there are also challenges to the NEP that have led to a negative view of the NEP. Among them are complaints that were also rife about the NEP's pro-Malay bias due to non-Malay Bumiputeras; the Orang Asli (the aborigine) and some Sabah and Sarawak indigeneous communities have failed to make any significant gains in ownership and control. The poor non-Bumiputeras had benefited least from the NEP. This is the first challenge of NEP.

The second challenge is the "ALI BABA" practice. Such practices failed to create meaningful partnerships in business between Bumiputeras and non-Bumiputeras, damaging the promotion of Bumiputera business, and as a result the Bumiputeras are still backward in large businesses in term of business skills and experiences. This practice has long been condemned by the government (See for example "UMNO General Assembly Presidential Speech" New Straits Times, 26-5-84).

The third challenge is the NEP was also branded a new Malay capitalist class policy. Those who had strong positions in the free-market economy would be able to survive, otherwise they would be defeated. Malays from the upper and middle classes benefited most from the NEP. The majority of the Malays who formed the lower class was left behind. Therefore, the gap between the rich and poor became wider.

Husin (2008: 98-100) argued that the implementation of the policy within the laissez faire system only perpetuated greater socio-economic inequality, exploitation, and poverty among the people. The policy was also accused of favouring to assist Malay large business interests. Politically well-connected enterprises enjoyed better access to government-created rents, thus restricting small companies to accumulate capital. Small Malay enterprises have had to compete with companies owned or controlled by politicians which are generally assured of favourable government treatment, particularly in the award of licenses and contracts, and in terms of access to finance and information. UMNO leaders usually controlled large companies and enterprises. Therefore, the benefit deemed to go to themselves and their cronies (Ayed, 1988). Thus, the NEP can be seen to be directed more towards creating new Malay capitalist, cronies, and super-rich businessmen than eradicating poverty among the Malays themselves.

Despite criticism, the NEP achieved considerable success in reducing the poverty level although it was still acute in the rural areas. The nation was able to sustain its pace development, with GDP growing at an average rate of 6.7 per cent per annum during the NEP period, 1971-90 and 8.7 per cent during the Sixth Plan period. The per capita income in nominal terms increased from RM1, 106 in 1970 to RM9, 786 in 1995. The rapid expansion of the economy has led to the decline of the unemployment rate to 2.8 per cent in 1995 (Prime Minister's Department of Malaysia. 1996). The incidence of poverty had fallen to 17.1 in 1990. Bumiputera private individual's share had increased from 39 per cent in 1983 to 68 per cent in 1990 (Gomez \& Jomo, 1997). Ownership of corporate capital with the target of 30 per cent by Bumiputera was not achieved. Racial economic disparity slightly improved during the NEP period. By the end of the 1980s, the identification of race with economic function or occupation and sectoral activity had been generally reduced. In the 1990's, the ownership of wealth continued to favour non-Malays. Overall, greater equality both within and between races had not yet been achieved in the 20 years of the NEP policy. 


\section{iv) Vision 2020 As a Continuation of the NEP}

Two months after the NEP ended, in February 1991 Mahathir presented his Vision 2020 plan. The Vision's main goal was for Malaysia to become a fully developed country by the year 2020 . The plan stressed an equally narrow, materialistic and economical emphasis on growth. The plan contained nine central strategic challenges and nine main objectives. The objectives were to establish:

- A united, peaceful, integrated and harmonious Malaysia nation.

- A secure, confident, respected and robust society committed to excellence.

- A mature, consensual and exemplary democracy.

- A 'fully moral' society with citizens strongly imbued with spiritual values and the highest ethical standards.

- A culturally, ethically and religiously diverse, liberal, tolerant and unified society.

- A scientific, progressive, innovative and forward-looking society.

- A caring society with a family-based welfare system.

- An 'economically just' society with inter-ethnic economic parity; and

- A 'fully competitive, dynamic, robust, resilient and prosperous' economy (Mahathir, 1991: $1-3)$.

The plan also can be regarded as a long-term economic plan. It "...continues to give serious attention to strategies for generating sustained rapid economic growth as well as to ensure that the benefits of economic growth are equitably shared among Malaysians of all ethnic groups and among States as well as the rural and urban population (Mahathir, 1991: 4)."

The vision has shifted attention away from the previous narrow accentuation on inter-race apportioning efforts. Vision 2020 commitment to create a bangsa Malaysia (Malaysian nation) transcending existing racial identities and loyalties has also created some enthusiasm among non-Bumiputeras (Gomez \& Jomo, 1997). According to Suriati (1999), Vision 2020 is merely a continuation of the NEP and positive discrimination favouring the Bumiputeras.

With the launching of the Seventh Malaysia Plan, 1996-2000, the Malaysian government hopes it will provide a stage for the government to accelerate the attainment of the objectives of balanced development with the overriding objective of creating a more united and just society (The Government of Malaysia. 1996).

Since the $15^{\text {th }}$ century, there were already socio-economic relations between the Malays and other ethnic groups through trade, involvement in government and mixed marriages in both the lower and upper strata of the society. At that time the position of the Malays and the government was strong since the non-Malays were few and some of them came only for a short time. Those who settled were easily assimilated into Malay society (Husin, 1985: 109110).

Malaysian society has gone through a unique experience in building a socio-economic civilization. In 60 years, many Chinese and Indians have succeeded in the business world compared to the Malays. There is no denying that efforts for the development of all races produce a harmonious life. Thus, a thorough understanding of the social reality of Malaysian society is important in the appreciation of ethics and civilization.

\section{Ethnic Diversity and the Appreciation Ethics and Civilisation in the Malaysia Historical Context}

Throughout history we will be able to see the level of appreciation of ethics and civilization of Malaysian society. The level of appreciation of ethics and civilization is influenced by the 
development of its history beginning with the Malay sultanate of Melaka and the arrival of the West to the Malay world. During the Pre-Colonial Period, the Malay community has a high level of behavior and character. The Malay Muslim community in history proves that they have reached a very glorious era of civilization (Osman, 2018).

i) Malacca Straits As The Venue of Diversity and the Malacca Sultanate As The Symbol of Multi-ethnic Society Cultural Interaction

Malacca is called The Venice of the East which is a meeting place for traders from all over the world such as from Arabia, Persia, China, India and so on. The greatness of the Melaka empire became a meeting place for traders from all over the world, so much so that it was called 'The Venice of the East'. The age is the golden age of the Malacca Sultanate and the height of the Malay royal majesty (Yusoff, 1992). The zenith of Malacca can be seen from the aspects of government, trade, population and culture.

The openness of the government of the Malacca empire to accept the presence of traders from all over the world without strict conditions caused the port of Malacca to develop as the most important port in the world. The development of trade and the empire of Malacca as a metropolitan city made Malacca a multicultural city. Every culture in Malacca has its own place. Cultural pluralism is not a new phenomenon in the Malay world. The interaction of various cultures such as the pre-Islamic Arabs, Hinduism, Buddhism, Islam and Europe such as Portuguese, Spanish, Dutch and British in the Malay culture has occurred since the 5th century AD. The meeting of the world and the clash of cultures has produced a special feature of social phenomena in the Malay world, namely plurality and cultural phenomenon. Malacca Sultanate era was the golden age and the height of the Malay royal majesty. Melaka is ruled by farsighted sultans and dignitaries (Yusoff, 1992).

ii) The Administration of The Malacca Sultanate Era (1400-1641)

The grandeur of the Malacca Sultanate empire building aided by the position of the Malay Land is strategically located in the heart of the trade route. The presence of the Chinese in the Malay Land began through trade relations (Borschberg, 2020). Similarly, foreign traders from Arabia, India and Europe concentrated in Malacca and many of them settled in Malacca and married local women. Malacca Sultanate is very important in the history of Malaysian Government not because it is a very influential throughout the Malay Archipelago, but the starting point of socio-political traditions of the Malays in Malaysia. The majesty of the Malacca Sultanate has recorded rule, rule of law and the subsequently adopted by the government after it.

The political system of society during these days is simple in nature. People who are used to being leaders are the elders in the society such as penghulu, batin or chief. Then this small group developed into a larger society, then appointed officials such as the rich, the great people or the king. Malacca Sultanate is an example of the height of the Malay political system with the rather complex but regular and even regarded as a cohesive feudal order. The social system is divided into four types of community groups, namely, family, residential area, descent and interests. This social system has a wide social distance in traditional times but after the arrival of the British this system began to split with the factors of urbanization, industry, administration as well as politics and education (Borschberg, 2020). The resulting effects can be viewed from three angles. That is, the changes that take place in the groups in 
the traditional society, the social problems that arise and the new groups that emerge in the society.

There are three layers of society, namely the upper layer, middle layer and lower layer. The upper echelons used to be Sultans and magnates but now there are politicians, administrators and senior managers. The middle layer, if previously did not exist but now this layer consists of government administrative officials. While the lower layer is large among the Malays there are two groups, farmers and workers.

During the zenith of the Malacca Empire and before the arrival of British power, the Malays economically dependent mainly on agriculture and business, and those kings and princes still remains as the party that controls the economy, as how they dominate politics. The development of plantations, mining and trade strengthened the capitalist economic system which was based on financial economy after the presence of British power because they had very large capital (Yusoff, 1992).

The diversity of a pluralistic society began to grow again in the presence of the Portuguese, Dutch and British in Malay Land and has brought in many immigrants from China and India, leaving a legacy to the extent that now the existence of the Peranakan community. The Malays of the provinces of the archipelago also migrated to Malay Land. Given the position of the Malay border with Indonesia, the country became the focus of the mass exodus of residents from across the land. In the $14^{\text {th }}, 15^{\text {th }}, 16^{\text {th }}$ and $17^{\text {th }}$ century, Malay Land saw the migration of Javanese, and Bugis Minagkabau. The main factor of this migration was due to the strict Dutch government policy and coercion implemented in mainland Indonesia. There is also a pull factor of the capitalist economic policies and free trade system practiced by Britain and the British East India Company in the Malay Land.

\section{iii) The Formation of a Plural Society in the British Colonial Era}

The arrival of the British in the Malay world based on a three-pronged, namely religion, wealth and splendor. A separation between religion and science occurred in Europe (15th century AD). Religion is considered a contributor to disagreements among humans, fights and wars. In the 18th century, the British East India Company had expanded its economic power in the eastern continent in search of supply of the resources to cater the industrial revolution. Initially, the British are not keen to expand its power in the Malay Archipelago. This is because the Malay Archipelago at that time under the influence and power of the Netherlands. As enshrined in the Anglo-Dutch treaty of 1824, under which neither party would interfere in the colonies of the other party (Abdul Rahman, 2000).

In 1786, Francis Light was anchored in Penang. The state was later handed over to the British by the Sultan of Kedah as protection from the Siamese threat. The action of British political interference on the Malay Land began in 1874, namely in Selangor, Negeri Sembilan and Pahang. In 1895, four states have been consolidated into a federation known as the Federated Malay States. This new administration structure inherited until now, namely the establishment of the Conference of Malay Rulers. It was not until 1909 on the call for the centralization of administrative power to be distributed to the state government that finally the establishment of the Federal Legislative Council was implemented. This is the basis of the structure of the Federal Government found in the central government administrative system today. 
According to Nazaruddin, Nurazmi and Ismail (1996), the British colonial system not only has brought new administration but also introduced two other policies governing ethnic segregation in Malay Land at that time, namely, Divide and Rule. This policy has separated the three ethnicities according to settlement identification viz:

i. The Malays are more concentrated in rural areas and are mostly involved in farming and fishing economy.

ii. The Chinese are mostly concentrated in urban areas and work in the tin mining and service industries.

iii. The Indians were more concentrated in the plantations or rubber estates.

Divide and Rule Policy can also be seen as a British veto to regulate colonial structure, function and location of the economic and social functions of every ethnicity in Malay Land to facilitate their colonialism interest. This policy has left a chronic implication for Malaysian society to this day. The implication is that there is a segregation of economic structure and function as well as settlement areas according to race in Malaysia. Through this policy, the British had brought in foreign labor, mainly from China and India to meet the supply of cheap labor for the industries of the colonial capitalist economy in the country. The booming colonial rubber and tin economy at the end of the 19th century required a plentiful and cheap source of labor. Rhetoric that is often used is indigenous Malay society ignorant and lazy to carry out this new economic activity, with the British colonial immigration policy introduced which eventually form a compound of the Malay community that consists of three main ethnic Malays, Chinese and Indians.

\section{iv) The Era of Japanese Imperial Administration (August 1942 to September 1945)}

The era of Japanese administration has also left a mold on the pattern of ethnic relations in the country. Among them are the political consciousness and the rise of Malay nationalism to resist the invaders. Japan's policy that prioritizes the Malays have worsened inter-ethnic relations in Malaya, especially between the Malays and Chinese. Japan has promised to give independence to Malaya and the Malays should give cooperation to the Japanese. Malay Sultans are still allowed to use their titles without any power. Sultan task just as an advisor to the governor of Japan in each of the Malay States (Rohani \& Zulhilmi, 2002). Service to the Malays have been mistaken by the Chinese. They see the Malays as "stooges" of Japan. The result is that hostility between the Malays and the Chinese thicken during this era. This is because the Chinese have been treated badly by the Japanese. Japan has imposed various pressures and punishments on the Chinese. Japan has pursued a policy of extermination and punishment.

As compared to the Chinese, the Indians get good treatment. As state efforts to conquer India, Japan has instructed the Indians in Malaya to concentrate their politics to political developments taking place in India which is against British rule. The Indian Nationalist Army and the Indian Liberation Alliance were formed to liberate India from British occupation. These organizations have raised awareness in politics and nationalism spirits of the Indians against the Indian State and ignore the pressures of political exclusion in Malaya then. The occupation of Japan for 3 years and 8 months ended August 15, 1945. The Japanese administration has brought suffering to the people of Malaya. Japanese government has been worsening race relations in the Malay world, especially among the Chinese and Malays. 


\section{v) The Era of Independence (1957-1969) and Nation-State Building Progress}

An important implication of the Japanese occupation was the birth of a strong spirit of nationalism among the Malays, Chinese and Indians. The British returned to Malaya intending to change its status to British colony through what is called the Malayan Union. Malayan Union was seen by the Malays as a program that only benefit the immigrant population and the legal aspects of the Malayan Union which is said to threaten the privileges of the Malays.

After the Malayan Union was canceled, the British established the Federation of Malay States (1948) in order to fulfill the British aspiration to free Malaya from its protection. The new constitution has restored the sovereignty of the Malay rulers, establishing the Legislative Assemblies of each of the states in Malaya, tighten the terms of nationality, review the privileges of the Malays, to increase the number of members of the Federal Council of Legal from 48 members to 75 members (including representatives from the Chinese, Indians and indigenous peoples) and relaxed the conditions for granting citizenship status to foreigners according to the period of residence in the country.

The first General Election was held on July 27,1955. The Alliance Party won 51 of the 52 seats contested. The President of the Alliance Party, YTM Tunku Abdul Rahman Putra, has been elected to lead the new government that will be formed. This is an important boost for the people of Malaya towards self-government of a free and independent government. This has led to the independence delegation to London in January 1956, which subsequently led to the independence of Malaya on August 31, 1957.

The draft constitution for the Federation of Malay Land independence was agreed on August 15, 1957. The people of Malay Land agreement on the terms of the 1957 Constitution indicates racial tolerance in the country. It also represents a compromise between the political parties of UMNO, MCA and MIC related issues on citizenship status, the special position of the Malays and the issue of the national language. Political and social tolerance is important for the cooperation of all races in the Malay Land in developing and promoting the economic, social and political future of the country after independence. Cooperation and tolerance between the three largest races is also a condition that has been imposed by the British towards an independent country.

After independence and after the formation of Malaysia in 1963, the government realized that one of the main problems that would hinder the development, progress and modernity of Malaysia was national integration. The government's main challenge is to unite the various racial groups in Malaysia into one territorial system to create a national identity. Among the steps that have been taken by the government to realize national integration are:

1. Reducing psychological differences between the population in each region in Malaysia.

2. Overcome the problem of geographical differences by closer relationships and interactions so that there is a better understanding between the population and all existing races.

3. Creating a common identity which is a symbol of loyalty and commitment to the concept of Malaysian nationalism (INTAN, 1994).

The formation of Malaysia in 1963 has further shaped the plural society in Malaysia with the presence of Sarawak and Sabah indigenous communities. The indigenous people of Sarawak or Bumi Kenyalang consist of various ethnics. The largest number is the Iban (Sea Dayak), followed by Malays, Bidayuh (Land Dayak) and Melanau. Meanwhile, the minority groups of Sarawak's indigenous people are Kenyah, Kayan, Kedayan, Murut, Kelabit, Bisayah, Punan, Penan and others. Meanwhile in Sabah, the Kadazan Dusun community is the largest 
indigenous people in Sabah. This community makes up 98.2\% of the total population of Sabah. There is also a Murut community who live in remote residences from Keningau to the border of Sarawak and the province of Kalimantan, Indonesia. The indigenous people of Sabah who live in the coastal areas are the Bajau. Other indigenous communities living on the coast of Sabah are the Kedayan, Bisayah, Ilanun, Suluk and Tidung communities. The Malays are minority in the state.

The ethnic diversity that emerges in the life of traditional communities may have long been inherited, including in the life of communities in Malaysia. According to the sociological view, ethnic consciousness or a traditional cultural group is transformed into an ethnic group only in the process of the emergence of modern society. To understand the emergence of ethnic diversity in Malaysia in general, as well as in any other society, a general perspective based on the life experiences experienced by the people in the history of old societies as well as modern societies can be used as a platform. In every society, the rise of ethnicity shows a history of its own. It showcases the different experiences that are continuously experienced by cultural communities in the process of formation and development of modern society. This situation is especially evident in the process of modern nation-building, especially after achieving independence from colonial powers.

\section{Conclusion}

The importance of appreciation of ethic and civilization is in building the Malaysian nation to be united and for its citizens to live in harmony, as well as being a developed and prosperous nation. The early history of the people of Malay Land has strong ties to a group of natives of this country that is the aboriginal. Aboriginal people also known as Proto-Malay. The Orang Asli are divided into several ethnic groups, namely Jakun, Temuan, Semelai and Orang Laut. While the Malays and Orang Asli are the indigenous people of the Malay Land, but the presence of other races has much influence and change the social system of the Malay community. This process of change has already left a significant impact on the entire social system of the country. In general, there are three major ethnic groups in Malaysia, namely Malays, Chinese and Indians. There are also minorities such as Eurasian, Bengali, Punjabi and Europeans along with these three largest races.

The paradigm of history of multiracial society in Malaysia started since the Malay Malacca Sultanate. The chronology of the development of this society in the era of the Malacca Sultanate era later extended to the intervention of external forces in Malay Land in 1800.

Managing the plural society in this beloved country is the main focus to ensure the stability, harmony and well-being of the people. This effort has been going on for more than half a century and has always been dynamic in the nature of its approach. Since achieving independence from the British colonialist in 1957, the country's leaders have always managed 'weaknesses' among the various ethnic and religious groups in the country. The method used to manage ethnic relations has been termed as 'local politics' which is essentially based on the principles of bargaining, cooperation and acceptance among different ethnic groups. Although this peaceful atmosphere is sometimes felt to be precarious with the existence of loopholes that can undermine the unity formed, the government has worked through 'national unity' and 'national integration' approaches and constant reminders to the public about the importance of managing unity. 
We are convinced that the concept of ethics and civilization should refer to the understanding of the historical context in the Malay world starting from the Sultanate of Melaka. In fact, the Malay community has had a long experience and interaction with other Asian ethnic groups such as the Chinese and Indians. This study has also discussed the open attitude of the Malay community in the economic context from pre-colonial to post-colonial era by highlighting the government's efforts through the NEP and vision 2020. Malaysia's national agenda that has not been fully completed since Merdeka is the formation of a truly intact Malaysia. among the multiracial society in Malaysia. Therefore, the Malaysian society needs to appreciate the concept of Malaysian ethics and civilization to create a Malaysian nation that can be united and live-in harmony and ready to face all the challenges that lie ahead.

\section{References}

Abdullah, A. R. H. (2000). Wacana falsafah sejarah: perspektif barat dan timur. Utusan Publications \& Distributions.

Ishak, A. (1995). Pendidikan Islam dan pengaruhnya di Malaysia. Dewan Bahasa dan Pustaka. Hussein, S. A. (1988). Islam and politics in Malaysia, 1969-1982: the dynamics of competing traditions (Doctoral dissertation, Yale University).

Al-Ghazali, A. H. M. B., \& Imam, M. (2003). Ihya' 'Ulum ad-Dīn, Jilid 2 dan 4. Kaherah: Maktabah as Safa, cetakan ke-1.

Abdullah, A. A. (c.ed). 2012. Isu-isu sensitif dalam hubungan etnik di Malaysia. Serdang: UPM Press.

Abdullah, A. A. (1990). Konsep akhlak Islamiah menurut Imam al-Ghazali (Doctoral dissertation, Fakulti Usuluddin, Akademi Islam Universiti Malaya).

Abdullah, A. A. (2014). Islam yang dinamik. Serdang: Penerbit Universiti Putra Malaysia.

Arnold, T. W. (1968). The preaching of Islam, Lahore: Ashraf Press.

Deraman, A. A. (1992). Tamadun Melayu dan pembinaan bangsa Malaysia. Dewan Bahasa dan Pustaka.

Blagden, C. O. (1924). A note on the Trengganu inscription. Journal of the Malayan Branch of the Royal Asiatic Society, 2 (3 (92), 258-263.

Borschberg, P. (2019). The Melaka Empire, c. 1400-1528. In Empires of the Sea (pp. 263-293). Brill.

Byrne, P. (1992). The philosophical and theological foundations of ethics: An introduction to moral theory and its relation to religious belief. Basingstoke, United Kingdom: Palgrave MacMillan.

Cham, B. N. (1977). "Colonialism and communalism in Malaysia". Journal of Contemporary Asia, vol. 7, no. 2. 197-220.

Peng, C. F. (2003). Peranan sastera kebangsaan dan persepsi dalam pembentukan perpaduan nasional: Satu kajian di negeri Selangor dan Wilayah Persekutuan Kuala Lumpur (Doctoral dissertation), Unpublished. Universiti Kebangsaan Malaysia, Bangi.

Chuen, C. K. (1982). "The New Economic Policy - Trends and implications" in Federal Territory MCA Liaison Committee (ed). The Malaysian Chinese: Towards national unity, Kuala Lumpur: Federal Territory MCA Liaison Committee. 20-30.

Comber, L. (1983). May 1969: A historical survey of Sino-Malay relations. Singapore: Graham Brash.

Faaland, J., Parkinson, J. R., \& Saniman, R. B. (1990). Growth and ethnic inequality: Malaysia's new economic policy (NEP). Chr. Michelsen Institute. 
Fatimi, S.Q. (1963). Islam Comes to Malaya. Singapore: Malaysian Sociological Research Institute Ltd.

Furnivall, J. S. (1948). Colonial policy and practice: A comparative study of Burma and Netherlands India. Cambridge: Cambridge University Press.

Gomez, Edmund Terence and Jomo, K. S. (1997). Malaysia's political economy. London: Cambridge University Press.

Gomez, E. T. (1994). Political business: Corporate involvement of Malaysian political parties. Centre for South-East Asian Studies, James Cook University of North Queensland.

Hall, D. G. E. (1981). History of South East Asia. Macmillan International Higher Education.

Harrison, B. (1954). South-east Asia: A short history. Macmillan.

Musa, H. (2002). "Strategi membangunkan peradaban Malaysia: Perspektif peradaban Islam Melayu", Seminar Nilai-nilai Peradaban dan Wawasan 2020, organized by Pusat Dialog Peradaban Universiti Malaya.Kuala Lumpur.

Sawabi, H. Y. (2012). "Masyarakat Suluk: Cabaran dan harapan dalam menjana transformasi etnik Suluk", in Mohd. Rosli Saludin and Mohamed Fazil Ajak (Editor). Menjana trasnsformasi etnik Suluk. Sungai Buloh: Venton Publishing Sdn. Bhd. 1-16.

Hirth, F., \& Rockhill, W. W. (1966). Chau Ju Kua: His work on Chinese and Arab Trade in XII and XIII Centuries, St. Petersburg: Paragon Book.

Hua, W. Y. (1983). Class and communalism in Malaysia: Politics in a dependent capitalist state. Zed Books.

Ali, S. H. (2008). The Malays: Their problems and future. The Other Press.

Ngah, I. (1993). Business activities in new townships in rural areas of Peninsular Malaysia (Doctoral Dissertation), University of Leeds (School of Geography)).

INTAN. (1994). Malaysia kita. Kuala Lumpur: INTAN.

Hamid, I. (1986). The Earliest Centers Of Islamic Studies In The Malay World. Hamdard Islamicus, 9.

Chin, J. (2010). Malaysia: The rise of Najib and 1Malaysia. In Southeast Asian Affairs 2010 (pp. 165-179). ISEAS Publishing.

Jesudason, J. V. (1989). Ethnicity and the economy: The state, Chinese business, and multinationals in Malaysia. Oxford University Press, USA.

Kamus Dewan Edisi Ketiga. (1994). Kuala Lumpur: Dewan Bahasa dan Pustaka.

Siu, L. C. (1972). Ikhtisar Sejarah Kesusasteraan Melayu Baru 1830-1945. Antara.

Lim, M. H. (1985). Affirmative action, ethnicity and integration: The case of Malaysia. Ethnic and Racial Studies, 8(2), 250-276.

Mahathir, M. (1991). Malaysia: The way forward. Malaysian Business Council. Kuala Lumpur. Masumi, M. S. H. (1992). Imām Rāzī's 'Ilm al-Akhlāq. New Delhi: Kitab Bhavan.

Mills, L. A. (1958). Malaya: A Political and Economic Appraisal. U of Minnesota Press.

Misbaha. (1959). Pesaka Suci atau Batu Bersurat Trengganu, Singapore, Al-Ahmadiyah Press.

Morrais, F. (1974). "If Only the Trengganu Stone Could Speak", New Sunday Times, February 15, 1974.

Hashim, M. Y. (1989). Kerajaan Melayu Melaka. Kuala Lumpur: Dewan Bahasa \& Pustaka.

Abd Muis, M., Bakar, B. A. M., Rahman, A. A., Zakaria, Z., Noordin, N., \& Nordin, J. (2012). Ethnic plurality and nation building process: a comparative analysis between Rukun Negara, bangsa Malaysia and 1 Malaysia concepts as nation building programs in Malaysia. Asian Social Science, 8(13), 153. 
Abd Razak, N. S., \& Husin, W. N. H. W. (2011). Hubungan Sosial Antara Komuniti Mela Yu Den Gan Komuniti Bukan Mela Yu Mengikut Perspektif Peradaban: Satu Pengenalan. Jurnal Pengajian Melayu/Journal Of Malay Studies (Jomas), 22(1), 205-233.

Paterson, H. S. (1924). An early Malay inscription from Trengganu. Journal of the Malayan Branch of the Royal Asiatic Society, 2 (3 (92), 252-258.

Prime Minister's Department of Malaysia. (1996). Seventh Malaysia Plan 1996-2000, Kuala Lumpur: Prime Minister's Department.

Ratnam, K. J. (1967). Communalism and the political process in Malaya, Kuala Lumpur: University of Malaya Press.

Ratnam, K. J. (1969). "Religion and Politics in Malaya" in R.O. Tilman (ed.). Man, state and society in Contemporary Southeast Asia, New York: Prager.

Roff, W. R. (1968). The Persatuan Melayu Selangor: An Early Malay Political Association. Journal of Southeast Asian History, 9(1), 117-146.

Ross-Larson, B. (1980). "Social and Political Setting" in Kevin Young, W.C.F. Bussink, and Parvez Hasan (eds.). Malaysia: Growth and ethnicity in a multiracial society, Baltimore: The John Hopkins University Press, 12-22.

Ali, S. H. (1985). The Malays: Their problems and future, Kuala Lumpur: Heinemann Asia.

Selvaratnam, V. (1974). Decolonization, the Ruling Elite, and Ethnic Relations in Peninsular Malaysia. Institute of Development Studies.

Shellabear, W. G. (1961). Sejarah Melayu or The Malay Annals, Singapore: Malay Publishing House.

Shibutani, T., \& Kwan, K. M. (1965). Ethnic stratification, London: The Macmillan Company.

Silcock, T. H., \& Aziz, A. (1953). "Nationalism in Malaya" in W.L. Holland (ed.). Asian nationalism and the West, New York: The Macmillan Co. 280-294.

Smith, T. E., \& Bastin, J. (1967). Malaysia. London: Oxford University Press.

Suriati Ghazali. (1999). Socio-economic changes in the peri-urban villages in Penang, Malaysia, Ph.D Thesis (unpublished), School of Geography, University of Leeds.

Shamsul Amri Baharuddin (C.ed.). (2012). Modul hubungan etnik edisi kedua. Kuala Lumpur: Penerbit Universiti Malaya.

Shamsul Amri Baharuddin. (2008a). Hubungan etnik di Malaysia: Mencari dan mengekalkan kejernihan dalam kekeruhan. Siri Kertas Kajian Etnik Bil.1. Universiti Kebangsaan Malaysia.

Shamsul Amri Baharuddin. (2008b). Many ethnicities, many cultures, one nation: The Malaysian experience. Siri Kertas Kajian Etnik Bil.2 Universiti Kebangsaan Malaysia.

Shamsul Amri Baharuddin. (2009). Culture and governance in Malaysia's survival as a nation. Siri Kertas Kajian Etnik Bil.3 Universiti Kebangsaan Malaysia.

Shamsul Amri Baharuddin. (2010). Unity in diversity: The Malaysian experience. Siri Kertas Kajian Etnik Bil.13 Universiti Kebangsaan Malaysia.

Ahmad, S. H. (1988). Islam and politics in Malaysia, 1969-82: The Dynamics of the competing traditions. Ph.D Thesis (unpublished). Yale: Yale University.

Ali, S. H. (2008). Ethnic relations In Malaysia: Harmony \& conflict. Vinlin Press Sdn. Bhd.

Teo Kok Seong. (2010). Malaysia's ethnic relation: The Challenges 50 years ahead, in Jabatan Perpaduan Negara dan Integrasi Nasional. Managing success in unity. Jabatan Perpaduan Negara dan Integrasi Nasional. 179-214.

The Government of Malaysia. (1971). Second Malaysia Plan 1971-1975. Kuala Lumpur: Government Printer. 
The Government of Malaysia. (1996). Seventh Malaysia Plan 1996-2000. Kuala Lumpur: Government Printer.

The Merriam Webster Dictionary. (2016). Springfield, United States of America: Merriam Webster, U.S.A.

Peh, T. C. (1980). Konsep asas sosiologi. Kuala Lumpur: Dewan Bahasa dan Pustaka.

Husin, W. N. W. (2012). Peradaban dan perkauman di Malaysia: hubungan etnik Melayu-Cina (Penerbit UM). The University of Malaya Press.

Hassan, W. Z. (2010). Sadd al-Dharâ'i' dalam memelihara agama dan kaitannya dengan asas keharmonian hubungan etnik. Jurnal Pengajian Umum. Bil. 6 Pusat Pengajian Umum, Universiti Kebangsaan Malaysia, Bangi.

Winstedt, R. O. (1961). The Malays: A cultural history. London: Routledge \& Kegan Paul.

Hashim, M. Y. (1992). The Malay sultanate of Malacca: a study of various aspects of Malacca in the 15th and 16th centuries in Malaysian history. Dewan Bahasa dan Pustaka.

Ramli, Y. M., \& Jusoh, T. G. T. (2012). Najib Razak's 1Malaysia and Charter of Medina's One Ummah: Comparative Perspective. International Journal of Business and Social Science, 3(2). 26-36.

Abdul Wahid, Z. A. (1980). "Merdeka" in Zainal Abidin bin Abdul Wahid (ed.). Glimpses of Malaysian history. Kuala Lumpur: Dewan Bahasa dan Pustaka, Kementerian Pelajaran Malaysia. 155-162. 